\title{
Operational control of white pine blister rust by removal of lower branches
}

\author{
by R.S. Hunt ${ }^{1}$
}

\begin{abstract}
Line surveys were conducted in 13 young western white pine (Pinus monticola D. Don) stands throughout British Columbia to determine the effectiveness of lower branch removal in controlling blister rust (Cronartium ribicola Fischer). Uninfected trees and most trees with infected branches were protected from future stem infections. In general, effectiveness and efficiency could have been improved by (a) earlier treatment to reduce stem infections, (b) not treating trees with infected stems, (c) treating all other trees, and (d) removing infected branches above the treatment height. Some stands were spaced during treatment; however, untrained fallers failed to distinguish between healthy trees and those with infected stems. Frequently healthy trees were felled while diseased trees were left standing. A pretreatment survey is recommended to determine the level of crew training needed and treatment prescription.
\end{abstract}

\section{Résumé}

Des inventaires par échantillonnage en lignes ont été effectués dans 13 jeunes peuplements de pin argenté (Pinus monticola D. Don) à l'échelle de la Colombie-Britannique pour déterminer dans quelle mesure l'enlèvement des branches inférieures des arbres permettait d'enrayer effectivement la rouille vésiculeuse (Cronartium ribicola Fischer). Les arbres sains et la plupart de ceux dont les branches étaient atteintes ont été protégés contre de futures infestations au niveau de la tige. D'une façon generale, le traitement aurait été plus économique et plus efficace si: (a) on l'avait appliqué plus tôt afin de prévenir l'infection des tiges; (b) on n'avait pas traité les arbres dont les tiges étaient déjà atteintes; (c) on avait traité tous les autres arbres; et (d) on avait supprimé les branches infectées se trouvant au-dessus de la zone de traitement. Certains des peuplements ont été éclaircis au cours du traitement. Cependant, à défaut de formation, certains abatteurs n'on pas pu distinguer les arbres sains de ceux dont les tiges étaient infectées, si bien que des arbres sains ont souvent été abattus, alors que des arbres malades ont été laissés sur pied. Les auteurs recommandent d'effectuer un inventaire prétraitement pour établir le niveau de formation que doit posséder l'équipe et la méthode de traitement qui convient.

\section{Introduction}

Western white pine (Pinus monticola D. Don) is a valuable tree species (Muir 1988) that is particularly desirable for planting in sites already invaded by root disease in the Pacific Northwest (Hunt 1987, Russell 1988a). However, blister rust, caused by Cronartium ribicola Fischer, may kill $95-99 \%$ of the white pine in plantations in about 20 years (Hunt and Meagher 1990), and $85 \%$ of the white pine in mixed natural stands may be killed before reaching merchantable size (Hunt 1982). Similarly, high losses are reported in non-resistant stock from Idaho (Goddard et al. 1985). There is some variation among stands; on steep sites stands suffer greater losses than on flatter sites (Hunt 1983a). The loss of white pine from the stand usually means it is replaced by a species of lower stumpage value and a species more prone to root disease. Controlling blister rust, particuarly on root disease sites, could be economically and ecologically advantageous.

Since $75 \%$ of blister rust cankers in British Columbia occur within $2.5 \mathrm{~m}$ of the ground, complete removal of the lower branches (pruning) will theoretically permit $80 \%$ of white pine trees in the average stand to survive to merchantable size (Hunt 1982). Likewise, observations in Washington (Russell 1988b) as well as in Idaho and Montana (Hagle et al. 1989) indicate that small trees have most blister rust cankers in the lower crown, thus pruning the lower branches before the cankers reach the main stem may permit many trees to reach merchantable size. Experimental prunings carried out

${ }^{1}$ Forestry Canada, Pacific Forestry Centre, 506 W. Burnside Rd., Victoria, B.C. V8Z 1M5. by trained workers (Hunt 1986, Beale 1988, Russell 1988b, Hagle et al. 1989) have generally been very successful; however, in one study, blister rust was not reduced when the treatment was combined with juvenile spacing (precommercial thinning) (Hungerford et al. 1981). The overall trend for white pine survival based on theoretical calculations and experimental prunings has resulted in hundreds of hectares being treated on an operational basis by various agencies in British Columbia. The object of this study was to evaluate the effectiveness of pruning by operational crews to control blister rust. Part of this work has been presented elsewhere (Hunt 1988a, 1988b).

\section{Methods}

Stands were surveyed in the year of treatment (1983-1984), either before pruning or shortly after pruning in untreated control strips (initial surveys). Although 19 stands were treated, only 13 could be reached before treatment or had an ample control strip left for surveying. They were natural stands (mixed), about 20 years of age (Table 1), from throughout British Columbia (Fig. 1).

Nine of the 13 stands were spaced and pruned at the same time. The recommendation at the time of treatment was to fell S-cankered trees (trees with stem cankers) (Hunt 1983b); thus, an effective job would have eliminated S-cankered trees and permitted the remaining trees to grow. Most S-cankered trees have a characteristic orange color in the stem, but branch cankers, close to the stem $(0-5 \mathrm{~cm})$, also, have viable mycelium in the stem, but lack orange color. These also should be classified as S-cankers. Surveying immediately 
Table 1. Stocking density of white pine before and after treatment.

\begin{tabular}{|c|c|c|c|c|c|c|c|c|}
\hline \multirow[b]{3}{*}{ Stand } & \multirow{3}{*}{$\begin{array}{l}\text { Age } \\
(\mathbf{y r})\end{array}$} & \multicolumn{3}{|c|}{ Treatment } & \multirow{2}{*}{\multicolumn{2}{|c|}{ Area sampled }} & \multirow{2}{*}{\multicolumn{2}{|c|}{ Stocking (stems/ha) ${ }^{2}$}} \\
\hline & & \multirow{2}{*}{$\begin{array}{c}\text { Area } \\
\text { (ha) }\end{array}$} & \multirow{2}{*}{$\begin{array}{c}\text { Pruned } \\
(\%)\end{array}$} & \multirow[b]{2}{*}{ Spaced } & & & & \\
\hline & & & & & $\left(\mathrm{m}^{2}\right)^{1}$ & (\% of treatment) & Before & After \\
\hline 1 & 20 & 13 & 53 & Yes & 1368 & 1.1 & $504(248)$ & $94(50)$ \\
\hline 2 & 25 & 12 & 71 & $\mathrm{Yes}^{3}$ & 900 & 0.7 & $967(474)$ & $956(612)$ \\
\hline 3 & $15-30$ & 1.5 & 100 & No & 6000 & 40.0 & $108(68)$ & $99(73)$ \\
\hline 4 & $5-20$ & 17 & 82 & Yes & 3270 & 1.9 & $647(227)$ & $346(159)$ \\
\hline 5 & 20 & 17 & 76 & No & 1428 & 0.8 & $239(70)$ & $365(203)$ \\
\hline 6 & $15-21$ & 6 & 71 & No & 4140 & 6.9 & $202(116)$ & $194(133)$ \\
\hline 7 & 15 & 8 & 99 & No & 4545 & 5.7 & $163(74)$ & $176(126)$ \\
\hline 8 & 20 & 2.5 & 100 & Yes & 1592 & 6.4 & $1811(1378)$ & $804(656)$ \\
\hline 9 & $12-30$ & 3 & 79 & Yes & 1200 & 4.0 & $942(669)$ & $482(197)$ \\
\hline 10 & 18 & 3 & 99 & Yes & 2400 & 8.0 & $454(259)$ & $325(254)$ \\
\hline 11 & 19 & 20 & 100 & Yes & 800 & 0.4 & $675(537)$ & $421(384)$ \\
\hline 12 & 20 & 8 & 94 & Yes & 2400 & 3.0 & $462(152)$ & $126(53)$ \\
\hline 13 & 18 & 6 & 100 & Yes & 2400 & 4.0 & $479(37)$ & $120(42)$ \\
\hline mean & & & 86 & & 2496 & 6.4 & $589(331)$ & $347(226)$ \\
\hline
\end{tabular}

${ }^{1}$ Initial, pre-treatment survey.

${ }^{2}$ First number is the total stem tally, the second number are healthy stems only, i.e. free of $\mathrm{S}$ and $\mathrm{T}$ cankers.

${ }^{3}$ Largely eliminating hemlock and dead white pine.

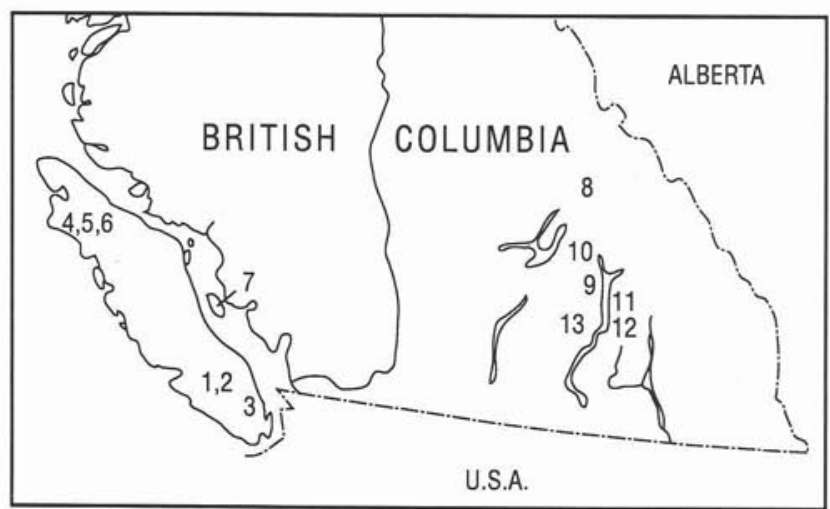

Figure 1. Southern British Columbia with numbered locations where pruning surveys were made to determine the effectiveness of pruning western white pine to control blister rust.

after pruning may give a false impression of the effectiveness of control, if these apparently healthy trees were left standing; thus, the pruning effectiveness survey was delayed for 4-5 years (1987-1989) (follow-up survey) after treatment.

In each stand, transects, 4-15 m wide, were run through a representative area, i.e. up and down the slope, rather than across the slope, and near the middle; or if more than one transect was used per stand, they were separated to divide the stand into similar proportions. Although a sample size of about 35 was sufficient to confidently calculate the percentage of trees saved (Hunt 1988b), a sampling safety margin of double this number was set as the minimum number to be sampled in each stand.

Each white pine was classified into one of three categories as follows:

(a) saveable by pruning, i.e. T-cankers (those threatening the stem which originate within $60 \mathrm{~cm}$ of the stem (Childs and Kimmey 1938) would be cut from the tree;

(b) not saveable by pruning, i.e. the tree had an S-canker including a T-canker within $5 \mathrm{~cm}$ of the stem, or a T-canker too high to reach by pruning; and

(c) healthy, i.e., pruning would not remove any T-cankers.
In the initial survey trees were also classifed as to whether they were pruneable only to $1.5 \mathrm{~m}$ or pruneable to $2.5 \mathrm{~m}$, i.e., leaving a minimum of two to three whorls on the stem and assuming workers would not reach above $2.5 \mathrm{~m}$. This gives a clear picture of the healthy stocking density and the potential gain by pruning, assuming all $\mathrm{T}$-cankers will become S-cankers and that there will be no additional Tcankers on the trees currently classified as healthy. If stands were spaced, the felled trees were also examined for blister rust in the follow-up survey.

Each unique stand has paired observations of stocking densities (Table 1) and blister rust incidence (Fig. 2). The variances among these factors are heterogenous and may reflect the effectiveness of individual crews; thus, statistical treatment has not been done. Trends within pairs of data are obvious; however, where they are useful, averages or ranges are presented.

\section{Results}

The follow-up survey indicated that some larger trees were pruned as high as $4 \mathrm{~m}$ and pruning to $3 \mathrm{~m}$ was common, rather than the expected $2.5 \mathrm{~m}$. Only five of the 13 stands in the initial survey had cankers above $3 \mathrm{~m}$, and then only 1 to $4 \%$ of the trees sampled. The initial surveys also revealed that the mean percentage of trees that could be saved by pruning was $22 \%$ (i.e. with T-cankers) in the 13 stands. The follow-up survey indicated that $6 \%$ (range $0-21 \%$ ) still could be saved by pruning (Fig. 2). This was largely because trees were missed in the first treatment (Table 1) or because there were new infections in trees not pruned to $3 \mathrm{~m}$. The average gain in healthy trees due to pruning was then $16 \%$ (range $0-34 \%$ ) (Fig. 2).

Before pruning, S-cankers were found on 19\% (range $2-39 \%$ ) of the small trees (i.e. those only pruneable to $1.5 \mathrm{~m}$ ) whereas, S-cankers were found on $39 \%$ (range $10-70 \%$ ) of the larger trees (i.e. those pruneable to $2.5 \mathrm{~m}$ ) (Table 2). An average of $85 \%$ of the S-cankers on the larger trees occurred below $1.5 \mathrm{~m}$ (Table 2). The mean percentage of S-cankered trees before treatment was 28 (range 7-49) and 29 (range 6-58) after treatment (Fig. 2). The four stands (\# 2, $8,9 \& 12$; Fig. 2) which had more stem cankers after treatment, than before, all had been spaced. 


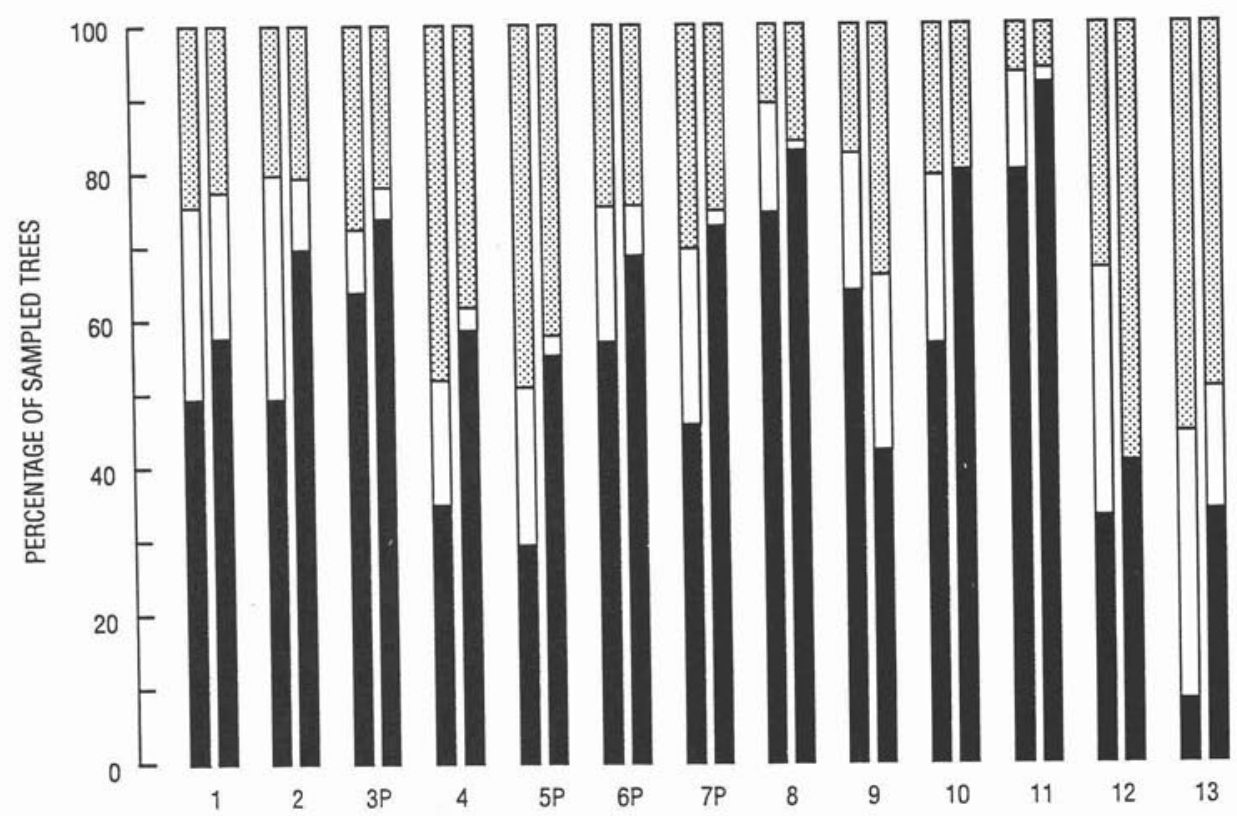

Figure 2. Incidence of S-cankers (stippled), T-cankers (clear) and healthy (black) white pines in thirteen stands before treatment (first bar) and 4-5 years after treatment (second bar). $\mathrm{P}=$ stand not spaced, but pruned only.

Table 2. Healthy and blister rusted (T- and S-cankers) white pines in two size classes: (a) those pruneable to $1.5 \mathrm{~m}$ (first number), and (b) those pruneable to $2.5 \mathrm{~m}$ (number in parentheses).

\begin{tabular}{|c|c|c|c|c|c|}
\hline \multirow[b]{2}{*}{$\begin{array}{c}\text { Stand } \\
\text { (no.) }\end{array}$} & \multirow[b]{2}{*}{$\begin{array}{c}\text { Sample } \\
\text { size }\end{array}$} & \multirow[b]{2}{*}{$\begin{array}{c}\text { Healthy } \\
(\%)\end{array}$} & \multirow[b]{2}{*}{$\begin{array}{c}\text { T-Cankers } \\
(\%)\end{array}$} & \multicolumn{2}{|c|}{ S-Cankers } \\
\hline & & & & $(\%)$ & $\begin{array}{c}\text { above } 1.5 \mathrm{~m} \\
(\%)\end{array}$ \\
\hline 1 & $16(53)$ & $37(53)$ & $37(23)$ & $25(25)$ & $0(8)$ \\
\hline 2 & $34(53)$ & $56(45)$ & $35(26)$ & $9(28)$ & $0(0)$ \\
\hline 3 & $23(42)$ & $74(57)$ & $4(9)$ & $22(33)$ & $20(14)$ \\
\hline 4 & $18(52)$ & $61(38)$ & $17(11)$ & $22(50)$ & $0(11)$ \\
\hline 5 & $24(54)$ & $50(20)$ & $37(13)$ & $12(67)$ & $0(8)$ \\
\hline 6 & $28(56)$ & $64(53)$ & $21(18)$ & $14(29)$ & $0(12)$ \\
\hline 7 & $31(43)$ & $52(40)$ & $16(30)$ & $32(30)$ & $0(0)$ \\
\hline 8 & $42(29)$ & $83(65)$ & $5(24)$ & $11(10)$ & 20(33) \\
\hline 9 & $58(55)$ & $76(49)$ & $14(25)$ & $10(25)$ & $0(14)$ \\
\hline 10 & $29(80)$ & $72(51)$ & $10(26)$ & $17(44)$ & $20(6)$ \\
\hline 11 & $42(12)$ & $86(58)$ & $12(17)$ & $2(25)$ & $0(33)$ \\
\hline 12 & $26(85)$ & $38(32)$ & $23(38)$ & $38(31)$ & $30(31)$ \\
\hline 13 & $54(61)$ & $17(0)$ & $44(30)$ & $39(70)$ & $0(21)$ \\
\hline mean & $\overline{34(55)}$ & $\overline{59(48)}$ & $21(23)$ & $19(39)$ & $7(15)$ \\
\hline
\end{tabular}

\section{Discussion}

Initial surveys indicated that about one-quarter of the white pine already had S-cankers, about one-quarter had T-cankers and about half were healthy. Other surveys (Buckland 1946, Thomas and Roff 1947, Hunt 1982, 1986, Hunt and Meagher 1989 ) indicate that most apparently healthy white pine will die before they reach merchantable size. However, this study shows that healthy trees can be protected by pruning. A pruning study of eastern white pine also documented the importance of pruning to protect healthy trees (Lehrer 1982).

Additionally, initial surveys indicated that nearly onequarter of the white pine needed immediate protection from T-cankers or they would probably develop S-cankers (Childs and Kimmey 1938). Follow-up surveys indicated that $72 \%$ of these latter trees were saved, although more could have been saved if infected trees had not been missed and if cankers above the pruning height and had been selectively removed or higher pruning had been attempted. The results showed that $85 \%$ of the S-cankers on trees pruneable to
$2.5 \mathrm{~m}$ occurred below $1.5 \mathrm{~m}$ (Table 2 ). In a previous study (Hunt 1982), 50\% of the S-cankers occurred below $1.25 \mathrm{~m}$ ( $75 \%$ below $2.5 \mathrm{~m}$ ). The sample in this earlier study was however, not representative of the stand since it only included larger trees, many of which had escaped infection at a young age. This new figure $(85 \%$ below $1.5 \mathrm{~m})$ is more representative; thus trees should be pruned to $1.5 \mathrm{~m}$ as young as possible. Delay will increase the incidence of S-cankers dramatically (Table 2,19 vs. $39 \%$ ). Additional protection can be achieved by later pruning to $3 \mathrm{~m}$, while little protection is achieved by pruning higher than $3 \mathrm{~m}$.

Treatment was expected to dramatically decrease the incidence of S-cankered trees, particularly in the spaced stands. However, this was not the case (Fig. 2, Table 1). Spacing in four stands increased the relative number of S-cankered trees, probably because the larger trees were retained and smaller trees felled; this was the case in stand 9 (Fig. 2). These larger trees were probably slightly older and more easily became infected when the stand was young and more open. 
To date there is no evidence of an absolute increase in stem cankers due to opening the stand by spacing, as occurred in Idaho (Hungerford et al. 1981).

In most spaced stands the relative number of S-cankered trees is similar before (mean 27\%) and after (mean 29\%) treatment (Fig. 2); although there were ample healthy trees to choose as leave trees (e.g. stand 1, Table 1), crews still left conspicuously S-cankered trees standing. Moreover, in every stand, trees with large stem cankers were pruned. Obviously, drastic spacing operations that fell healthy trees and leave diseased ones potentially create future stocking problems, and crews that prune doomed trees are wasting their effort. The problems encountered in this study emphasize the need for proper crew training prior to treatment. Alternatively, earlier pruning will largely obviate these problems.

Western white pine appears abundant in young-growth mixed stands, probably because it frequently projects above the canopy. The stocking density is then falsely viewed as high - so much so that some foresters believe that ample white pine will survive without pruning. However, if root disease is a concern, the stocking density of healthy white pine in most stands (mean of $331 \mathrm{stem} / \mathrm{ha}$; pre-treatment survey Table 1) is already below that of a fully-stocked stand (600-800 stem/ha). These poor stocking densities do not support the do nothing approach; to maintain stocking densities, healthy trees and branch infected trees must be protected by proper pruning. If a site is planted at a normal density of about $1100 \mathrm{stems} / \mathrm{ha}$, and then pruned as soon as possible to $1.5 \mathrm{~m}$, i.e. leaving two whorls, this should initially produce about 900 disease free stems/ha (19\% average loss in small trees; Table 2). Based on mean values, about 65 more will later develop S-cankers above $1.5 \mathrm{~m}$ $(39 \% \times 15 \%+19 \% \times 7 \%$; Table 2$)$, thus still leaving more than $800 \mathrm{stem} / \mathrm{ha}$ in typical plantations. If alternate hosts are nearby, higher initial losses can be expected. Overplanting may help compensate for such losses. If the site is on a slope, more losses may be expected from additional cankers above $1.5 \mathrm{~m}$ (Hunt 1983a), so a second pruning to $3.0 \mathrm{~m}$ is more important. Early pruning will largely restrict the losses to small trees which may reduce the need to have a trained crew to identify trees with infected stems during spacing. However, a pre-treatment survey (Hunt 1988b) is recommended that will predict the gains from various treatments and determine the level of expertise needed during pruning and spacing operations.

\section{References}

Beale, J.D. 1988. Evaluation of low-branch pruning for control of white pine blister rust. In R.S. Hunt (compiler) Proc. Western White Pine Management Symposium. Nakusp, B.C. May 2-5, 1988 p. 63-68. (Cited with permission.)
Buckland, D.C. 1946. Interim report on the effect of blister rust damage to the management of western white pine in the Upper Arrow forest. Can. Dep. Agric., For. Path. Victoria, B.C. mimeo,

Childs, T.W. and J.W. Kimmey. 1938. Studies on probable damage by blister rust in some representative stands of young western white pine. J. Agric. Res. 57: 557-568.

Goddard, R.E., G.I. McDonald and R.J. Steinhoff. 1985. Measurement of field resistance, rust hazard, and deployment of blister rust-resistant western white pine. USDA For. Serv. Res. Pap. INT-358.

Hagle, S.K., G.I. McDonald and E.A. Norby. 1989. White pine blister rust in northern Idaho and western Montana. USDA For. Serv. Gen. Tech. Rep. INT-261.

Hungerford, R.D., R.E. Williams and M.A. Marsden. 1981. Thinning and pruning western white pine: a potential for reducing mortality due to blister rust. USDA For. Serv. Res. Note INT-322.

Hunt, R.S. 1982. White pine blister rust in British Columbia I. The possibilities of control by branch removal. For. Chron. 58: $136-138$.

Hunt, R.S. 1983a. White pine blister rust in British Columbia II. Can stands be hazard rated? For. Chron. 59: 30-33.

Hunt, R.S. 1983b. White pine blister rust in British Columbia. Can. For. Serv., Pac. For. Centre. FPL 26.

Hunt, R.S. 1986. Pruning white pine to control blister rust in British Columbia. West. Int. For. Dis. Work Conf. Proc. 34: 27-28.

Hunt, R.S. 1987. Is there a biological risk of western white pine provenances to root diseases? West. Int. For. Dis. Work Conf. Proc. 35: 29-33.

Hunt, R.S. 1988a. Operational control of white pine blister rust by pruning. Abst. Phytopath 78: 1533 .

Hunt, R.S. 1988b. Operational control of white pine blister rust by pruning and canker scribing. In R.S. Hunt (compiler). Proc. Western White Pine Management Symposium. Nakusp, B.C. May 2-5, 1988 p. 53-62.

Hunt, R.S. and M.D. Meagher. 1989. Survival of "resistant" white pine (Pinus monticola and P. strobus) in coastal British Columbia plantations. Can. J. Pl. Path. 11: 419-423.

Lehrer, G.F. 1982. Pathological pruning: a useful tool in white pine blister rust control. Pl. Dis. 66: 1138-1139.

Muir, J.A. 1988. Why manage western white pine. In R.S. Hunt (compilier). Proc. Western White Pine Management Symposium. Nakusp, B.C. May 2-5, 1988 p. 8-11 (Cited with permission.)

Russell, K.W. 1988a. Why manage for western white pine? Proc. West. For. Conf. Seattle WA Dec. 4-7, 1988 p. 120.

Russell, K.W. 1988b Management of western white pine in nurseries and plantations to reduce white pine blister rust. Proc. West. For. Conf. Seattle WA Dec. 4-7, 1988 p. 124-128.

Thomas, G.P. and J.W. Roff. 1947. Summary reports on white pine blister rust 1947 survey. Can. Dep. Agric., For. Path. Victoria, typewritten. 